University of Warwick institutional repository: http://go.warwick.ac.uk/wrap This paper is made available online in accordance with publisher policies. Please scroll down to view the document itself. Please refer to the repository record for this item and our policy information available from the repository home page for further information.

To see the final version of this paper please visit the publisher's website. Access to the published version may require a subscription.

Author(s): STEPHEN BROADBERRY and HERMAN DE JONG

Article Title: Technology and productivity in historical perspective:

Introduction

Year of publication: 2000

Link to published version:

http://dx.doi.org/10.1017/S1361491600000010

Publisher statement: None 


\title{
Technology and productivity in historical perspective: Introduction
}

\author{
STEPHEN BROADBERRY† AND HERMAN DE JONG \\ † Department of Economics, University of Warwick, Coventry CV4 $7 A L, U K$ \\ ₹ Department of Economics, University of Groningen, PO Box 800, $9700 \mathrm{AV}$ \\ Groningen, Netherlands
}

This collection of articles is the result of a workshop organised to consider technology and productivity in historical perspective, drawing in particular on the evolutionary approach. The workshop was organised by the N.W. Posthumus Institute for Economic and Social History, the Netherlands Institute for Advanced Study in the Humanities and Social Sciences (NIAS) and the Groningen Growth and Development Centre. Economic historians with backgrounds in both evolutionary and neoclassical traditions came together in the pleasant surroundings of the NIAS at Wassenaar in May I999, to re-examine technology and productivity experience in Europe since the Industrial Revolution. An important focus was provided by recent theoretical developments, which have seen the incorporation of many evolutionary ideas into mainstream economics. Until quite recently, there seemed to be little common ground between approaches to technology and growth based on Solow's (1956) neoclassical growth model and Nelson and Winter's (1982) evolutionary, neo-Schumpeterian model. Now, however, the evolutionary approach has entered the mainstream through the work of writers such as Grossman and Helpman (I99I) and Aghion and Howitt (1998) on endogenous innovation, and David (1985) and Arthur (1994) on path dependence. This is a particularly welcome development from the perspective of the European Historical Economics Society, the sponsors of the European Review of Economic History, holding out the promise of a genuinely 'historical economics'.

There were points of both disagreement and agreement between those starting from an evolutionary perspective and those starting from a neoclassical perspective, and this is reflected in the articles. Dealing first with the points of disagreement, those starting from the neoclassical tradition tended to see technological progress as shifting out a production function and hence leading to an increase in output per unit of input, while those starting from an evolutionary perspective remained sceptical of the value of working with a production function and emphasised the possibility of technology and productivity moving in different directions in the process of selecting applied inventions. Furthermore, whereas those starting from the evolutionary perspective tended to stress the possibility of market failure and saw government intervention to correct for this and coordination 
between firms in a positive light, those starting from the neoclassical tradition tended to stress the ability of vested interests to block progress through political lobbying or collusive behaviour and the negative effects of government intervention.

There was, nevertheless, much common ground. First, both groups agreed that when a new technology is first introduced, cost savings over the old technology are often quite small, so that competing technologies could coexist for quite some time. Second, there was agreement that further improvements to the new technology are needed before widespread diffusion occurs. Mokyr's (1990) distinction between macro and micro inventions was seen as useful here, with a macro invention such as the use of the steam engine in pumping water out of mines requiring adaptation and improvement through micro inventions before it could be applied across a wider range of activities such as driving machinery in cotton mills, or powering locomotives on railways. Third, both groups recognised the possibility of 'reverse causation', that technology may be influenced by growth as well as vice versa. Fourth, there was agreement that the distinction between capital accumulation and technical change is difficult to make in practice because of complementarities.

Turning to the individual articles, Nicholas von Tunzelmann opens the volume with a broad overview of the relationship between technology and growth, starting from the evolutionary perspective. Patents, the output of specifically identified technology sectors and education are all examined as indicators of technical progress and related to growth performance. There is much in his discussion of the diffusion of technology within industries, across industries and across countries that a neoclassical writer would be able to agree with. Nevertheless, von Tunzelmann is also critical of the neoclassical approach in places, emphatically rejecting the use of a production function and stressing the positive effects that may be expected from government intervention to correct for market failures.

John Cantwell provides a detailed analysis of patent statistics, which he uses to calculate Revealed Technological Advantage (RTA). For the large firms in each selected country, Cantwell collects data on the number of patents taken out in the United States in each industry, since the United States has been the most important market in the twentieth century. For each industry, he then calculates the share of patents taken out in the United States by each national group of firms. In industries where a national group of firms has a higher share of patents than for industry as a whole, that national group is said to have a revealed technological advantage, by analogy with the idea of revealed comparative advantage for a country.

Cantwell shows that there has been a high degree of persistence in RTA for large companies since 1920, and this is interpreted as being consistent with the evolutionary idea that technological change is cumulative, incremental and path-dependent. Some industries clearly fit this pattern rather 
well. For example, in the chemical industry, German firms have retained a RTA for the whole of the period. In other cases, however, there have been large shifts of RTA, and this might be equally consistent with a leap-frogging model with investment in specific human capital (Brezis et al. 1993). In pharmaceuticals, for example, Cantwell draws attention to the strong position of British firms in medical and related technologies in the nineteenth century, the strength of German firms from the late nineteenth century on the basis of organic chemistry, and a renewed strong performance by British firms in recent years with the growing importance of biological science.

Should governments intervene to shape RTA? Cantwell's pharmaceuticals example suggests that there may be important spillovers between sectors within a country (in this case from chemicals to pharmaceuticals via organic chemistry), so that the development of clusters should be encouraged. However, a more neoclassically inclined writer might caution against governments 'picking winners' and point to costly errors as well as successes.

Lennart Schön examines the impact of a particular macro invention, electricity, on the Swedish economy, addressing issues concerning the productivity paradox and skill-biased technological change. Like von Tunzelmann and Cantwell, Schön starts from an evolutionary perspective, although his story also contains neoclassical elements. He identifies three periods of growth in electricity use per unit of output, between 1900 and I920, from the late I930s to the early I950s, and from the late I970s to I990. These developments coincide with falls in the price of electricity relative to the price of industrial production and other fuels. However, Schön does not leave the story with this neoclassical conclusion. Noting that relative price changes do not explain the whole picture, Schön argues that increasing electricity use coincides with 'transformation' phases of industrial development, which he sees as alternating with 'rationalisation' phases. This sheds light on the 'productivity paradox', or failure of the introduction of a major new technology to be accompanied by an acceleration of productivity growth. First noted in the context of the computer age, the same phenomenon was documented by David (I990) in the context of electrification in the United States. Schön now places the delayed acceleration of Swedish productivity growth after electrification in a general framework, with productivity growth being more rapid in rationalisation phases than in transformation phases. He then goes on to argue that transformation phases have been characterised by rapid growth in the demand for white collar workers, resulting in a complementarity between capital and skills, as suggested by Goldin and Katz (1996) for the United States.

There then follow two articles by authors starting from a more neoclassical position, but willing to incorporate insights from the evolutionary approach. Rainer Fremdling provides a case study of the diffusion of major innovations in the iron industry of nineteenth century Europe. He starts 
with a broadly neoclassical framework, with different local circumstances affecting market and cost conditions, and hence the profitability of the key innovations in different countries. An important distinction is made between the key innovations at three stages of the production process, with a shift from the use of charcoal to coke at the smelting stage, a shift from the use of charcoal to pit coal with the puddling process at the refining stage, and a shift from hammering to the rolling mill at the shaping stage. In some cases, the adoption of the modern process at one stage affected the viability of the old process at the other stage. Hence, for example, in the Champagne region, the adoption of the puddling furnace with pit coal at the refining stage reduced the pressure on charcoal prices and made the continued use of charcoal in the smelting process viable. The key factors affecting the speed of diffusion of the modern techniques included tariffs, energy costs and the price and availability of capital and skilled labour. This article provides an excellent template for writing the economic history of a major European industry.

Jan-Pieter Smits, in his study of Dutch manufacturing during the nineteenth century, notes that it is possible to tell a very neoclassical story for the period between I865 and I895. During that thirty year period, there was a surge in labour productivity, which can be explained by an increasing capital-labour ratio, which can be explained in turn by developments in relative factor prices. Smits argues, nevertheless, that these neoclassical relationships did not hold during the periods I8I5-I865 and I895-I913. To explain this, he appeals to two factors which do not appear in the basic neoclassical model, but which can nevertheless be incorporated in modern neoclassical models of endogenous growth that incorporate insights from the evolutionary approach. The first factor is demand, which can play an important role in a world of increasing returns to scale. Smits argues that Dutch industry was held back by the low level of consumer demand for industrial products in the first half of the nineteenth century. From the I860s, however, the rising real wage that provided the incentive to substitute capital for labour in production also increased the purchasing power of workers, and hence the demand for industrial products. The second factor that can be used to supplement the basic neoclassical story is the institutional setting. An important aspect of this is the extent of imperfect competition and the level of patenting activity, which can be in general incorporated in a model of endogenous innovation (Romer 1990).

These articles reflect the current state of historical economic research in the field of technical change and productivity growth in Europe. They also suggest that further research of a comparative nature, at the level of particular industries and sectors, as well as at the whole economy level, will be fruitful. It is clear, furthermore, that there is scope for improving the measurement of technology indicators and productivity levels on a comparative 
basis, in order to operationalise the claims of endogenous growth theory and evolutionary economics.

\section{References}

Aghion, P. and Howitt, P. (1998). Endogenous Growth Theory. Cambridge, MA: MIT Press.

Arthur, W. B. (1994). Increasing Returns and Path Dependence in the Economy. Ann Arbor, MI: University of Michigan Press.

Brezis, E. S., Krugman, P. R. and Tsiddon, D. (I993). Leapfrogging in international competition: a theory of cycles in national technological leadership. American Economic Review 83, pp. I2 I I-I9.

DAvid, P. A. (1985). Clio and the economics of QWERTY. American Economic Review Proceedings 75, pp. 332-7.

David, P. A. (1990). The dynamo and the computer: an historical perspective on the modern productivity paradox. American Economic Review Proceedings 80, pp. $355-6 \mathrm{I}$.

Goldin, C. and KATZ, L. (I996). Technology, skill, and the wage structure: insights from the past. American Economic Review Proceeedings 86, 252-7.

Grossman, G. M. and Helpman, E. (I99I). Innovation and Growth in the Global Economy. Cambridge, MA: MIT Press.

Mokyr, J. (1990). The Lever of Riches: Technological Creativity and Economic Progress. Oxford: Oxford University Press.

Nelson, R. R. and Winter, S. G. (1982). An Evolutionary Theory of Economic Change. Cambridge, MA: Harvard University Press.

Romer, P. M. (I990). Endogenous Technological Change. Fournal of Political Economy 98, pp. S7I-SIO2.

Solow, R. M. (1956). A contribution to the theory of economic growth. Quarterly Fournal of Economics 70, pp. 65-94. 